\title{
Wave energy potency in East Java coast
}

\author{
Heri Saptono Warpindyasmoro ${ }^{1}$ * \\ ${ }^{1}$ Electrical Engineering Department, Petra Christian University, Jl. Siwalankerto 121 - 131 \\ Surabaya, Indonesia
}

\begin{abstract}
It is predicted that in 2025, Indonesia energy needs is going to reach $280 \%$ of current needs. Presently, the renewable energy has only contributed $5.7 \%$ of total energy supply. The aim of this research is to investigate wave energy potency in several coasts of East Java which were Pacitan, Jember, Besuki and Tuban. Wave data (significant wave heights and wave periods) were obtained from the ERDDAP server (Environmental Research Division's Data Access Program). Southern East Java Coast showed potency for ocean wave energy resources. The coast of Pacitan had energy of $232 \mathrm{MWh} / \mathrm{m} /$ year and the coast of Jember had energy of $190 \mathrm{MWh} / \mathrm{m} /$ year.
\end{abstract}

\section{Introduction}

Energy demand in Indonesia has increased by $6 \%$ per year. In 2025, an increase of energy demands is likely to be $180 \%$ of present energy supply which means from 3 million BOEP (Barel of Oil Equivalent per Day) to 8.3 million BOEPD. Proportion of renewable energy supply among all energy sources was only $5.7 \%$. Ocean energy has long been studied by researchers both in Indonesia [1,2] and other countries [3]. The researcher have not only studied the source of ocean energy but also have studied technology of wave energy converter $[4,5]$ A study of wind, tidal, ocean currents and waves in the Sunda Strait as an alternative energy has previously been conducted [6]. It was found that Sunda Strait had waves with maximum wave height $3.2 \mathrm{~m}$ and periods 17 second which could produce $92 \mathrm{~kW} / \mathrm{m}$ energy. Furthermore, tidal energy was not feasible enough because the height was only about $0.5 \mathrm{~m}$ to $0.7 \mathrm{~m}$. Effect of wind on ocean wave in South Coast of West Java has also been studied [7]. In this study, it was found that wind and wave patterns varied greatly according to seasonal patterns. Tidal modelling has been conducted in Alas Strait (between Lombok Island and Sumbawa), the estimated energy obtained in one year was 330 GWh [8]. Researches have not only been conducted in Indonesia but also in Canary Islands [9] and Portuguese [10] where the prototype of ocean wave energy generation was made.

\footnotetext{
* Corresponding author: herisw@petra.ac.id
} 


\section{Research Methods.}

The power of ocean waves can be calculated as in equation $(1)[9,11]$

$$
P=\frac{\rho g^{2}}{64 \pi} H_{s}^{2} T_{e}
$$

where $P$ is the energy flux per width of wave $(\mathrm{W} / \mathrm{m}), H_{s}$ is the significant wave height (m), $T_{e}$ is the wave energy period (s), $\rho$ is the density of sea water $\left(\mathrm{kg} / \mathrm{m}^{3}\right)$ and $g$ is the acceleration of gravity $\left(\mathrm{m} / \mathrm{s}^{2}\right)$.

According to equation (1), significant wave heights and wave periods data are needed to calculate the power generated by sea waves. These data were obtained and provided by third parties. In this study, the data were obtained from https://coastwatch.pfeg.noaa.gov/erddap/index.html. ERDDAP (the Environmental Research Division's Data Access Program) was a server that provided oceanographic data. The data did not cover all ocean surface. However, it was recorded as points in a grid with $0.5^{\circ}$ space of latitude and longitude lines. Moreover, the data used in this study were from January 1, 2013 to December 31, 2013 which ware collected daily in every one hour. Figure 1 shows the location to be studied.

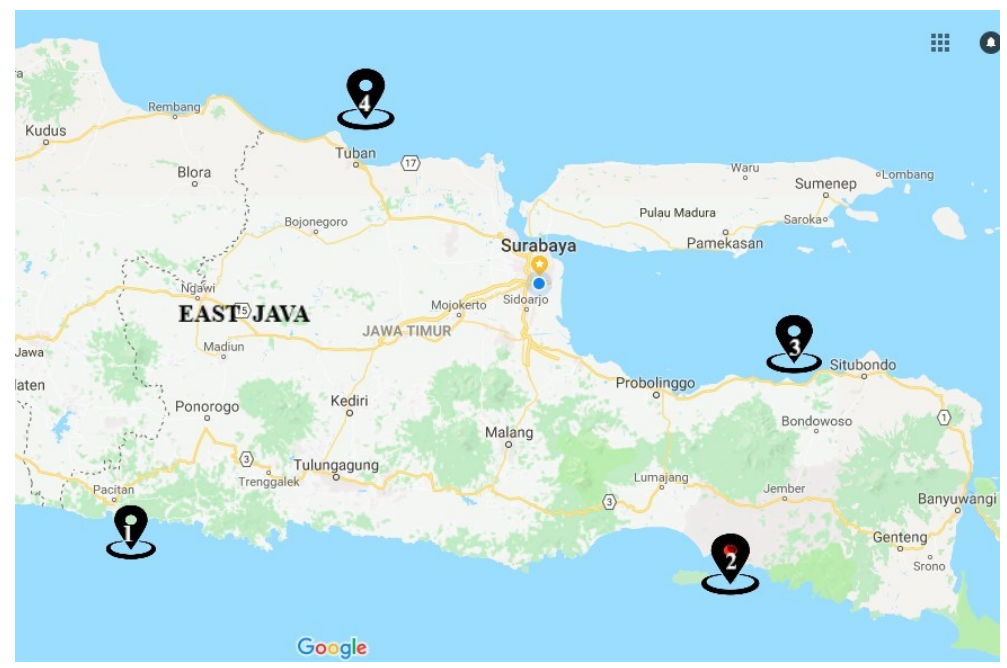

Fig. 1. The location of wave energy to be analysed, namely: Pacitan $(-8.5,111.0)$, Jember (-8.5, 113.5), Besuki $(-7.5,113.5)$ and Tuban $(6.5,112.0)$.

\section{Result and Discussion}

The four selected locations showed a noticeable different waves heights and periods. Waves on the north coast (Tuban and Besuki) had low significant wave height (less than $1 \mathrm{~m}$ ) and small period (2-8 seconds). On other hand, in the south coast (Pacitan and Jember), waves had a higher significant wave height (up to $4 \mathrm{~m}$ ) with a larger period (10 - 16 seconds). Wave spectrum for the four locations is shown in figure 2. 


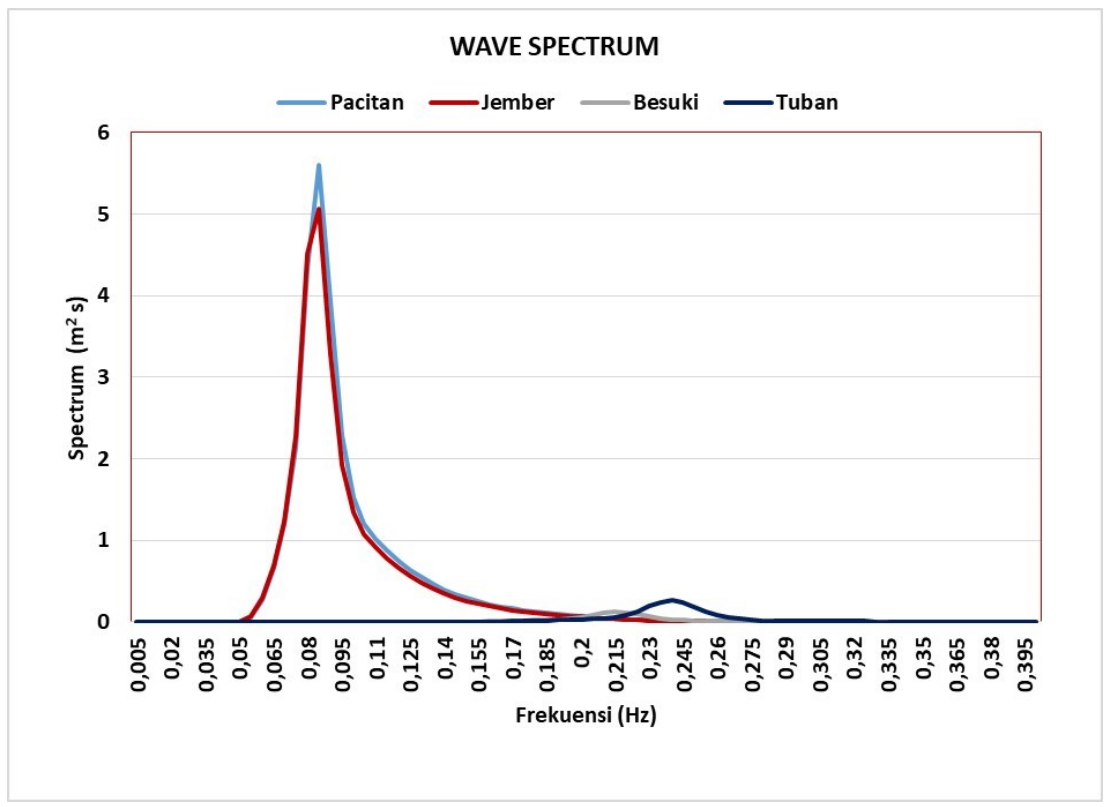

Fig. 2. Wave Spectrum.

Figure 3 - figure 6 show the waves energy flux which was calculated using equation (1). In Pacitan Coast, maximum wave energy was $232 \mathrm{MWh} / \mathrm{m} /$ year. Furthermore, in Jember coast, maximum wave energy was $190 \mathrm{MWh} / \mathrm{m} /$ year. On the other hand, Besuki and Tuban only produce energy respectively $8.6 \mathrm{MWh} / \mathrm{m} /$ year and $9.5 \mathrm{MWh} / \mathrm{m} /$ year. Thus the southern coast of Java produced energy of about $200 \mathrm{GWh}$ per $\mathrm{km}$ of beach within a year.

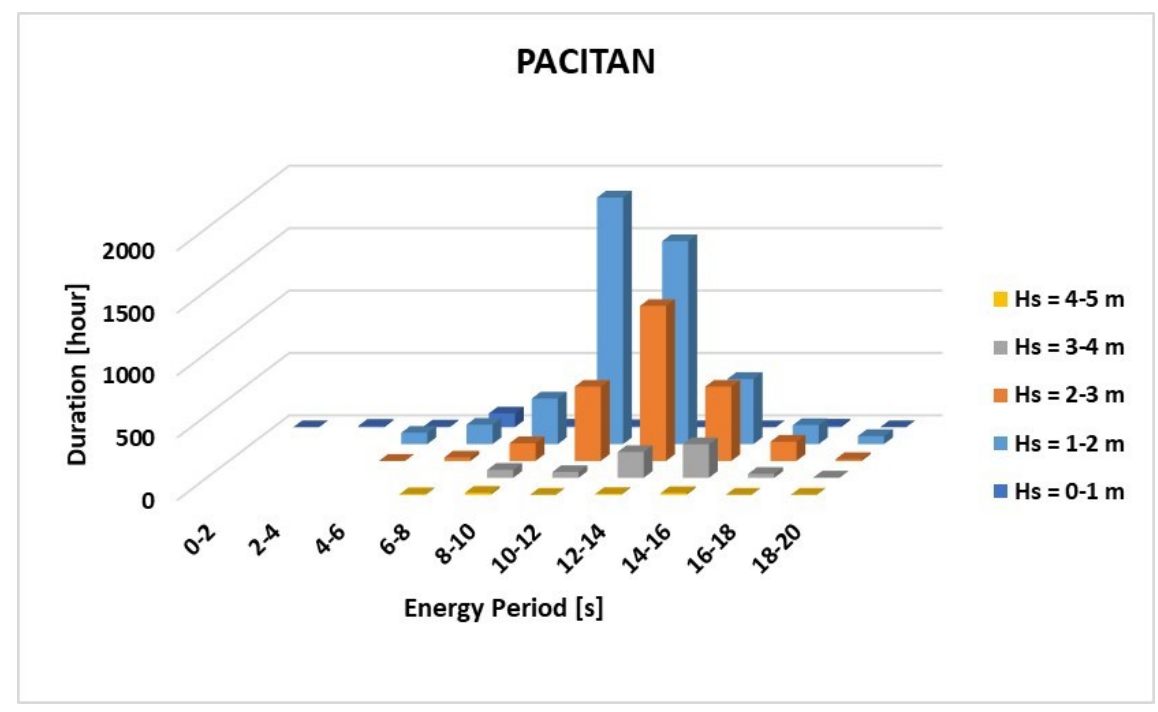

Fig. 3. Wave Energy in Pacitan 


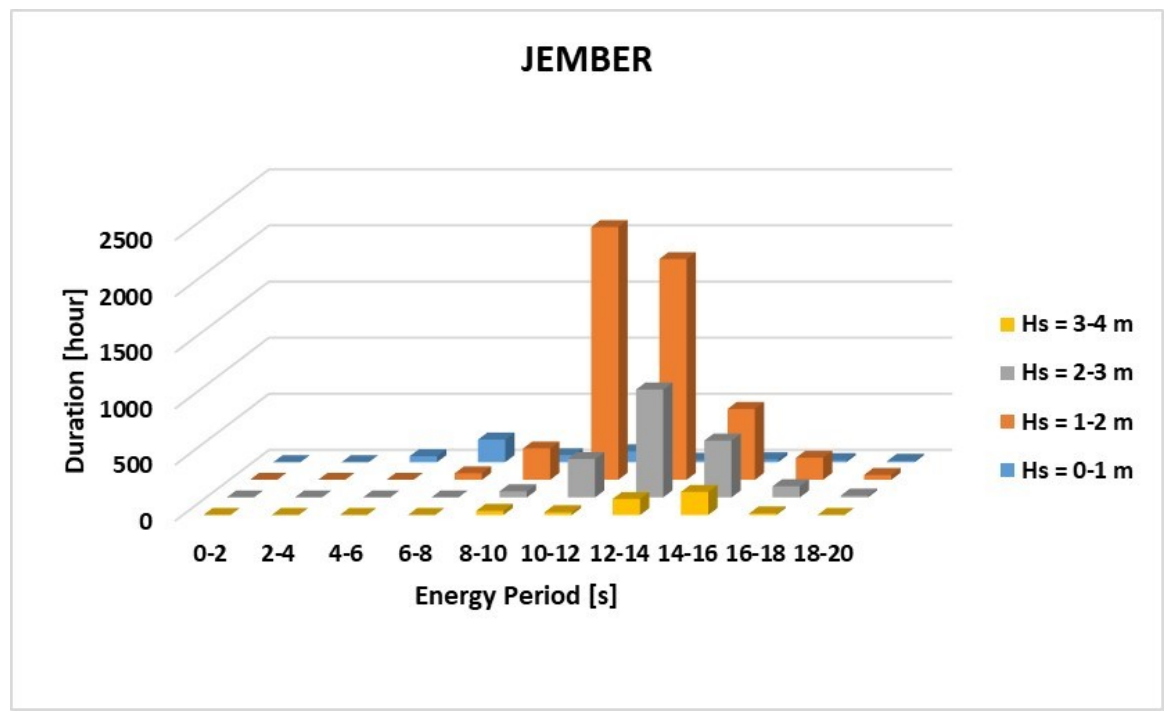

Fig. 4. Wave Energy in Jember

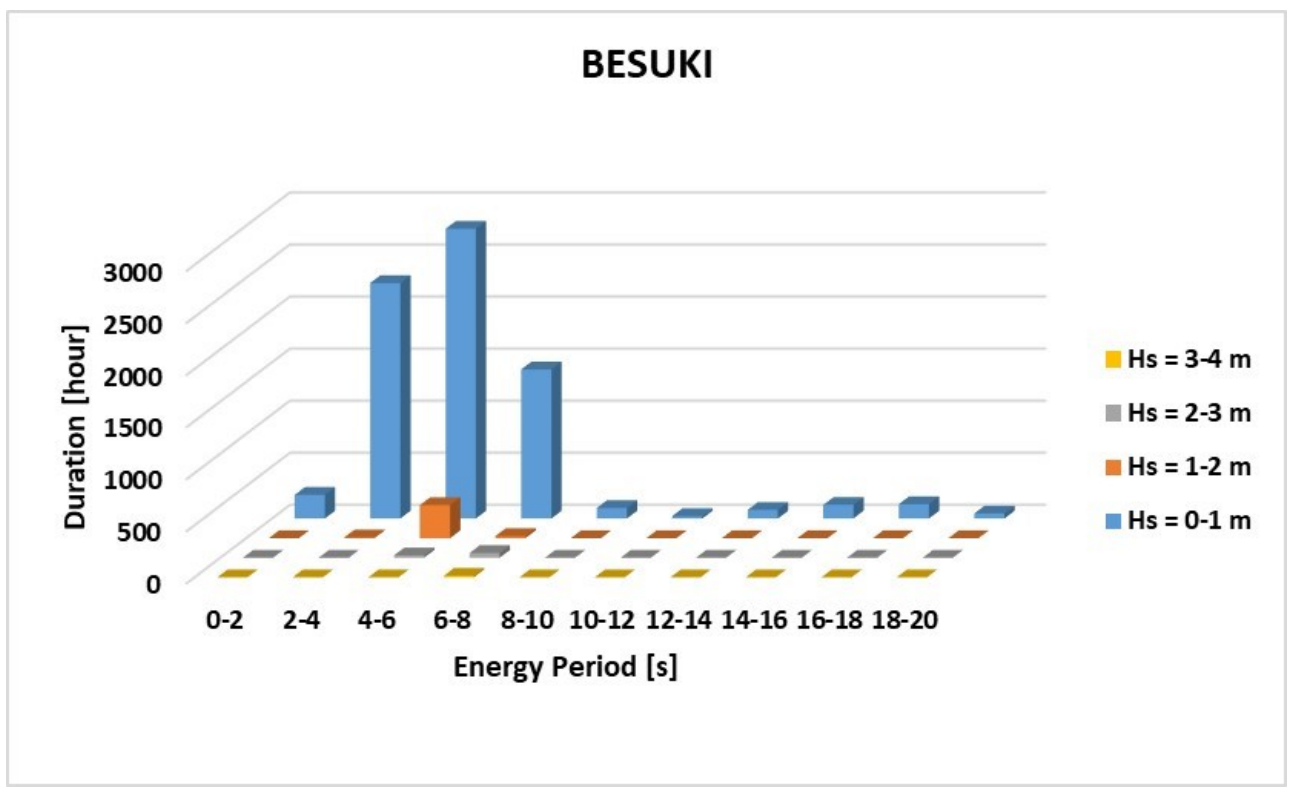

Fig. 5. Wave Energy in Besuki 


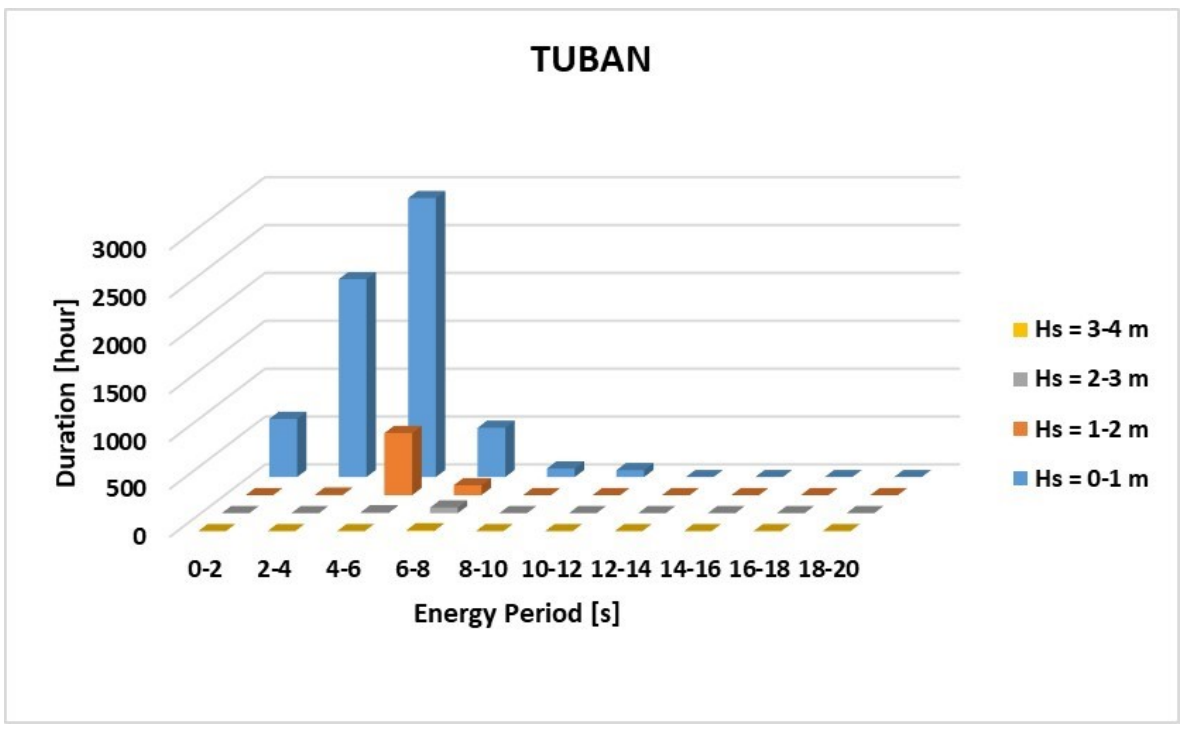

Fig. 6. Wave Energy in Tuban

\section{Conclusion}

The findings of the study could be revealed that the highest potency of wave energy to be converted into electrical energy in East Java occurred in the south coast of East Java. The coast of Pacitan had energy of $232 \mathrm{MWh} / \mathrm{m} /$ year and the coast of Jember had energy of $190 \mathrm{MWh} / \mathrm{m} /$ year.

\section{Reference}

1. D. Nugroho Sugianto, M. Helmi, I. Alifdini, L. Maslukah, S. Saputro, M. Yusuf, and H. Endrawati, IJMET, 8, 448-459 (2017)

2. D. Anggraini, M. I. A. Hafiz, A. F. Derian, Y. Alfi, IJST, 1, 228-239 (2015)

3. A. Cornett, Proc. ISOPE, 8, 318-326 (2008).

4. B. Drew, A. R. Plummer, and M. N. Sahinkaya, Proc. ImechE. Part A: J. Power and Energy, 223, 887-902 (2009)

5. J. Falnes, Marine Structures, 20, 185-201 (2007)

6. R. Sandro, Arnudin, A. Tussadiah, R. M. Utamy, N. Pridina, and L. N. Afifah, Energy Procedia, 47, 242-249 (2014)

7. N. P. Purba, J. Akuatika, 5, 8-15 (2014)

8. L. S. Blunden, A. S. Bahaj, and N. S. Aziz, Renew. Energy, 49, 137-142 (2013)

9. M. Gonçalves, P. Martinho, and C. Guedes Soares, Renew. Energy, 68, 774-784 (2014)

10. P. Mota and J. P. Pinto, Renew. Energy, 71, 8-17 (2014)

11. R. Atan, J. Goggins, and S. Nash, Energies, 9, 1-29 (2016) 